Jurnal ASPIKOM, Vol. 6, No. 2, July 2021, pp. 235-249

P-ISSN: 2087-0442, E-ISSN: 2548-8309

DOI: http://dx.doi.org/10.24329/aspikom.v6i2.906

\title{
Pandemic Journalism: A Study of Covid-19 News Coverage on detik.com
}

\section{Jurnalisme Pendemi: Studi terhadap Pemberitaan Covid-19 pada detik.com}

\author{
Benediktus Edi Woda, Mario Antonius Birowo*, Irene Santika Vidiadari, \\ Ranggabumi Nuswantoro \\ Universitas Atma Jaya Yogyakarta, Jl. Babarsari No.44 Yogyakarta, Indonesia \\ *Corresponding author, e-mail: mario.birowo@uajy.ac.id
}

\begin{abstract}
During a pandemic, people need information as a basis for knowledge and policymaking. This study aimed to describe the news about Covid-19 in the online media detik.com. This research used the quantitative content analysis method. The news from 688 articles with a period from 6 January to 9 March 2020 were collected. Disaster communication was used as a framework for understanding pandemic journalism. Pandemic journalism promoted health by presenting information that is ethical and scientifically based. News coverage during pandemics paid attention to vulnerable groups and expedited handling of pandemics. This study showed that news on detik.com is dominated by direct news 35\%, health themes 52\%, news with prevention dimensions $53 \%$, and $90 \%$ news using scientific terms without any explanation. The news detik.com is still working on presenting pandemic journalism.

Keywords: Covid-19; detik.com; Disaster communication; Online media; Pandemic journalism

Abstrak

Selama masa pandemi masyarakat membutuhkan informasi sebagai dasar pengetahuan dan pengambilan kebijakan. Penelitian ini bertujuan untuk menggambarkan pemberitaan Covid-19 dalam media daring detik.com. Penelitian ini menggunakan metode analisis isi kuantitatif. Berita dihimpun sebanyak 688 artikel dengan periode sejak 6 Januari hingga 9 Maret 2020. Komunikasi Bencana dipakai sebagai kerangka pemahaman untuk menjelaskan jurnalisme pandemi. Jurnalisme pandemi mempromosikan kesehatan dengan menampilkan informasi yang memerhatikan etika dan berbasis ilmiah. Liputan selama masa pandemi memerhatikan kelompok rentan dan memperlancar penanganan pandemi. Hasil penelitian ini memperlihatkan bahwa berita pada detik.com didominasi oleh berita langsung 35\%, tema kesehatan 52\%, berita berdimensi pencegahan 53\%, dan 90\% berita menggunakan istilah ilmiah tanpa disertai dengan penjelasan. detik.com masih berupaya menampilkan jurnalisme pandemi.
\end{abstract}

Kata Kunci: Covid-19; detik.com; Jurnalisme pandemi; Komunikasi bencana; Media daring 


\section{Introduction}

People are infected with Coronavirus Disease 2019 (Covid-19) worldwide. The scale of patients exposed to the disease widespread. Deaths are increasing every day (CDC, 2020; WHO, 2020). Meanwhile, several countries have not been responsive and ready to face this pandemic. Policies are considered unresponsive in handling this case. Everyone is encouraged and even emphasized to be vigilant and maintain the health of themselves and their environment. Leaders create various rules. They move swiftly to guard the community to be ready and resilient to face the pandemic (BNPB, 2020; Kemenkes, 2020; KSP, 2020; Local Government of DIY, 2020).

Covid-19 was first reported in Wuhan-Hubei City. Detection of Covid-19 began when China reported this case on 31 December 2019. Health authorities from China explained the presence of pneumonia with an unknown cause. The patients were traders at the Huanan Seafood market. Covid-19 became an epidemic when Korea, Japan, Thailand, and Singapore acknowledged the existence of this case on 23 January 2020. Since 11 March 2020 WHO has declared Covid-19 a pandemic (WHO, 2020). The number of confirmed cases as of 20 January 2021 was 96,625,755 confirmed, 2,065,698 died, and 69,299,279 recovered (Waldometer, 2021).

Supervision related to the Covid-19 virus in Indonesia began to be carried out intensively after the announcement of 2 positive cases on 2 March 2020 by the President. The government was criticized and judged not to be serious in handling this pandemic (Achmad, 2020). Controversion between governments exposed in the media. Misunderstandings about Covid-19, simplification of cases, different statements regarding the definition and development of cases, and less transparent, minimal, and inaccurate information exacerbate public understanding. The threat of Covid-19 continues to spread (Purnomo, 2020; Wisanggeni, 2020). The number of confirmed cases as of 20 January 2021 was 939,948 positive, 763,703 cases recovered, and 26,857 cases died (Kemenkes, 2021).

Since 13 April 2020, the President of the Republic of Indonesia, Joko Widodo, has declared the Covid-19 pandemic a national disaster through presidential decree number 12 of 2020 on the Determination of Non-Natural Disasters for the Spread of Corona Virus Disease (Covid-19). The rule on Law number 24 of 2007 about disaster management underlines that the government, the community, and the media have a role and responsibility in reducing disaster risk. However, Susanto (2011) emphasizes that the state has the authority to establish guidelines in disaster prevention, emergency management and rehabilitation and reconstruction in a fair manner while informing disaster management procedures. The government as an opinion leader is an entity that is obliged to build communication with the community through the media to educate the public in disaster management and management by providing information that supports a way of living together and respecting nature (Susanto, 2011; Wardyaningrum, 2018). In the context of a pandemic, the government becomes a helper who assists survivors, both community needs and sensitive information for victims (Sukmono \& Junaedi, 2018).

There are often problems with access to information when a disaster occurs. This happens because of unpreparedness to face disasters, both in terms of infrastructure and due to lack of knowledge about related disasters. However, communication must continue because communication is important for risk reduction and maintaining survivor resilience (Arif, 2010; Prajarto, 2008). Information is an important factor for the public to understand the disaster that occurred. So, they can act appropriately in 
times of disaster. Setio Budi HH (2012) emphasized that communication during disaster times is carried out with a comprehensive, systemic, integrated approach between institutions, components and existing stakeholders. It is because disaster management, communication, coordination and cooperation often experience obstacles. Communication is carried out with a focus and target on the audience by paying attention to the characteristics of the message and media. It is directed at building the spirit of survivors to recover.

Talking about the importance of communication, the implementation of largescale social restrictions (PSBB), social distancing (social distancing), working from home or WFH (Work From Home) during the Covid-19 pandemic disaster does not dim and cancel the communication process. The government and society are adapting to open up new spaces and ways in the communication process through digital technology (Febrina, 2020; Sinambela, 2020; Taher \& Abdi, 2020). When a disaster occurs, people need information as a source of understanding and taking action. The media can play a role in providing effective and efficient information. Puji Lestari (2019) stated that the media play social responsibility by providing accurate, free and ethical information. In addition, information during a disaster period must be fast, accurate, and precise in order to avoid confusing information (Budi HH, 2012). The demand for widespread to provide information to the public and other media becomes a problem for the accuracy of information. Therefore, Sukmono dan Junaedi (2018) recommend journalists to be careful and carry out in-depth verification so that there is no case of misinformation.

Lee Mordecai (2008) and Haddow dan Haddow (2014) seem to agree when underlining that disaster communication is understood as a comprehensive effort to prevent and reduce disaster risk with coordinated, timely, and easy-to-understand information. Meanwhile, Nunung Prajarto (2008) agreed that information during a disaster must be appropriate and comprehensive with clear and precise delivery to answer various questions, reduce fear, mobilize individuals and communities and mobilize actions to survive and recover. Regarding disaster information, Wardiyaningrum (2018) suggests the importance of integrating traditional knowledge and modern information as new knowledge to change people's attitudes and behavior in managing risk and tackling disasters. Therefore, information must be conveyed consistently (Paton \& Irons, 2016). Disaster situations require information from the stage of preparedness, early warning, mitigation, emergency response to the rehabilitation and reconstruction period (Arif, 2010). To support disseminating information to all society components, the government, including the private sector and community leaders, are fully involved (Susanto, 2011).

Today, the availability of fast information can be served by online media. Online media has the power of flexibility concerning time. This means that online media is faster in processing and distributing news. The internet, digital technology, and accessibility of information open up online media to develop (Wahl-Jorgensen \& Hanitzsch, 2019). In contrast to conventional media (newspapers, magazines), online media is faster to broadcast, real-time and quickly spreads. Online media can be broadcast anytime and anywhere, regardless of page and duration. The presentation of the news is presented in a concise format. Completeness of information is maintained because it can be linked (linkage/hyperlink). Errors, corrections, and updates can be made consistently and periodically to maintain readers' trust (Foust, 2017; Romli, 2012).

Media "detik.com" is an initiate of online news in Indonesia. Since 1998 detik.com displays fast, real-time, and updated information every minute (Anggoro, 
2012). Initially, "detik.com" was an independent media but since June 2011 detik.com shares have changed hands to CT Corp (Chairul Tanjung Corporation). This media has varied service categories such as Install Eyes, Adsmart, Forum, DetikEvent, Detik Point, Trans Snow World, and Trans Studio. The detik.com media network that is part of the Detik Network consists of CNN Indonesia, CNBC Indonesia, Hai Bunda, Insert Live, Beautynesia, dan Famale Daily (detik.com, 2020). Although it displays an element of dramatization, it is less objective. It sided with the "detik.com" company consistently and periodically displaying informative news widely accessed by readers (Lestari \& Rinasti, 2020). The center for media and communication studies in Indonesia ranked 4 for the accessibility level of the "detik.com" site with a score of 4.5 (Thaniago, 2020). Based on data compiled by "www.alexa.com", "detik.com" ranks in the top 5 most accessed sites in Indonesia with a presentation of living from each channel of $31.4 \%$ (Alexa, 2020).

Severa analysis studies on "detik.com" have been carried out using quantitative research methods, specifically examining the degree of objectivity, trend, and direction of online media coverage. Rahmayanti (2017) analyzed the issue of e-KTP corruption on the online media "detik.com" from 9-15 March 2017. In contrast to Rahmayanti, Luqman (2017) analyzed the Meikarta news for the period 1 August - 30 September 2017. Meanwhile, Cecilia, Boer dan Catherina (2020) conducted an analysis of the image of the Indonesian government at the opening ceremony of the 2018 ASEAN Games with a news time period of 18-20 August 2018. Research on "detik.com" was also conducted by Lestari dan Rinasti (2020). They chose news based on the August September 2017 time period and then explained it from the perspective of disaster journalism. Rahmayanti (2017) and Luqman (2017) use the Westrestahl Objective framework in seeing the trend of reporting on the "detik.com" portal. In addition, Jurgen Habermas' public space theory colors the findings of the analysis conducted by Luqman (2017). Meanwhile, Rahmayanti (2017) and Lestari and Rinasti (2020) dissect the online media of "detik.com" using Denis McQuail's social responsibility theory.

This study provides an overview of the trend of reporting about the Covid-19 pandemic on the online media "detik.com". The concept of disaster communication is used to explain the character of information on "detik.com" news through the perspective of Pandemic Journalism. News articles have been compiled since news about Covid-19 first appeared on the "detik.com" news portal, 6 January 2020 until one week after the confirmation of the case in Indonesia, 9 March 2020. This is important to see how far the "detik.com" news portal provides information about the Covid-19 pandemic and monitoring the process of handling the Covid-19 pandemic.

Journalism during the Covid-19 pandemic is a combination of health journalism, disaster journalism and empathy journalism (Yoedtadi, 2020). Disaster journalism puts forward information related to handling that seeks to reduce the danger and risk of additional victims (Haddow, 2014; Sanusi, 2018). This can be done before a disaster (pandemic), during a disaster and after a disaster. Meanwhile, empathy journalism avoids sensation and provides constructive attention and response to survivors (Lestari, 2019; Parahita, 2020). During a pandemic, journalists cover and provide evidence-based reporting accompanied by in-depth data and research because the public needs objective information (Arif, 2020; Yoedtadi, 2020). Information can be provided clearly and directly with a scientific approach based on skepticism and independence (Kemenristek/BRIN, 2020). Thus, pandemic journalism wants to provide health information before, during, and after a pandemic to reduce risk with ethical and 
scientifically based news that supports all efforts to handle the Covid-19 pandemic problem.

This study provides an overview of the news about Covid-19 on the online media "detik.com". This finding is expected to provide notes and contribute ideas about the coverage model during a disaster (pandemic). Thus, the discussions in this research become an evaluation for online media, especially "detik.com" in implementing pandemic journalism.

\section{Method}

Quantitative analysis was carried out to describe in detail the news about Covid19 in the online media "detik.com". The data is described systematically, factually and accurately about the facts and characteristics of the population (Sugiyono, 2015). News in "detik.com" is used as the object of this research. Data is collected by purposive sampling method. The researcher entered the keywords 'corona', 'Covid-19', and 'Wuhan pneumonia' in the search items in the online media portal. News articles, photos, and videos on "detik.com" from 6 January to 9 March 2020 became the population in this study. The news collected was 688 news.

The unit of analysis is based on the physical analysis unit and the thematic analysis unit. The physical analysis unit wants to see the text as a whole. The thematic unit wants to see the theme in a paragraph of a text as a whole. Ideas and ideas from a text are determined based on predetermined categories (Eriyanto, 2011). The unit of physical analysis that is seen is the form of news, and the use of scientific terms, and the thematic analysis unit that is considered is the theme of health and the dimensions of the news. The calculation results for the level of reliability of the coding sheet show a reliability number of 0.83 . This means that the coding sheet has a high level of reliability.

In addition, to observe the trend of reporting on the news page, the researcher did coding. Coding is done by grouping data into certain categories (Eriyanto, 2011). This study is conducted by the trend of various news related to COVID-19 and it can be described more clearly.

Data were analyzed using descriptive quantitative analysis techniques. After coding, the data were recapitulated using Microsoft Excel. Then, the data is described using a cumulative frequency table and displayed in the form of a diagram.

\section{Results and Discussion}

Researchers found and collected data of 688 news articles. The news categories collected on the "detik.com" page consist of: news, international news, finance, health detik, 20Detik, detikflash, food and detikinet. Then, the researcher conducted physical analysis and thematic analysis.

\section{Physical Analysis}

In the process of physical analysis, researchers make notes based on the physical size of a text. This means that the physical form of the text is measured as a whole. The physical cause of a text does not occur by chance but is planned by the author of the text. Physical appearance informs something that can be analyzed. This gives a different influence and understanding on the audience (Eriyanto, 2011). In this research, the physical analysis consists of: the form of news, and the explanation of scientific terms. 


\section{News Form}

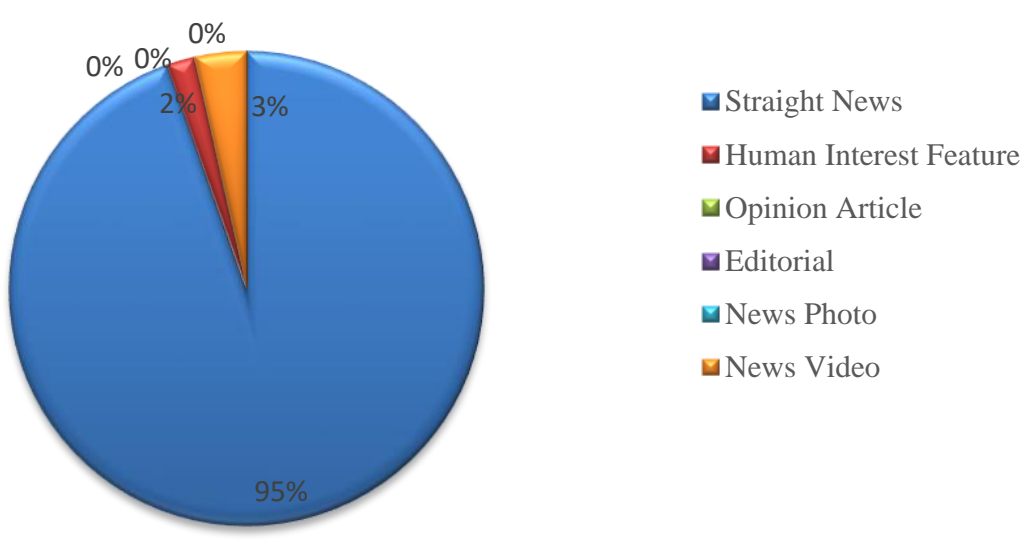

Figure 1. News Form on detik.com

Observing the news articles contained on the "detik.com" news page, it was found that the form of news was dominated by direct news. On "detik.com", there are 651 live news or $(95 \%)$. There are 13 news or $(2 \%)$ of human-interest features from 688 news collected from the media. At "detik.com" researchers did not find news in the form of opinion articles, editorials and news photos. This online media also displays news videos in its news portal. Shown 24 news or (3\%) in the form of video. This 20 -second video is included in the "DetikFlash" category.

\section{Use of Terms}

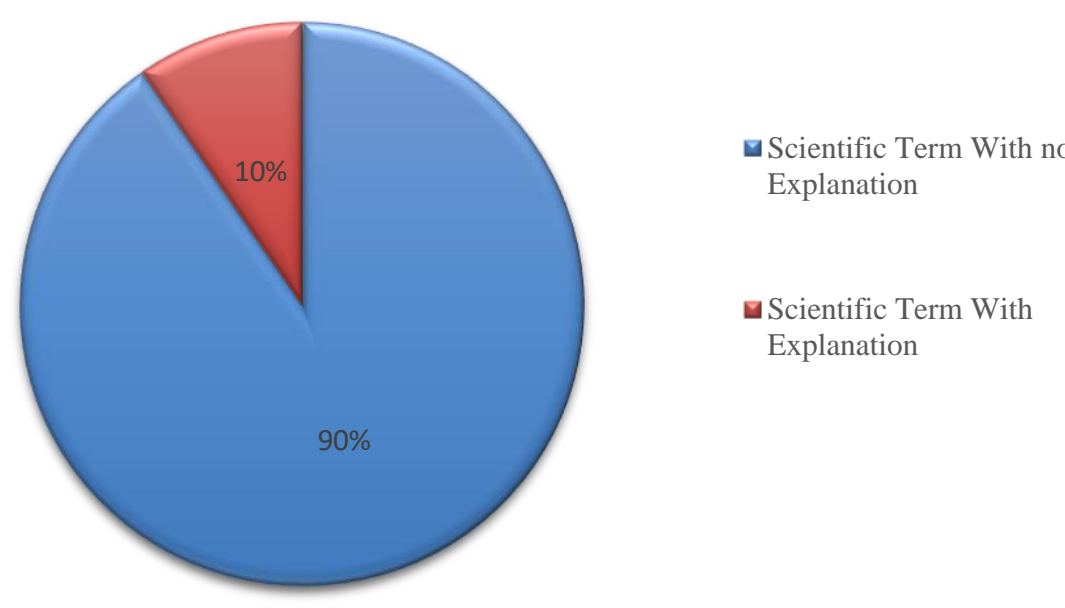

Figure 2. Use of Term on detik.com

This online media tends to display short news consisting of 6-10 paragraphs as many as 441 articles (61\%). Although the news is uploaded briefly, this news portal also displays information with terms accompanied by adequate explanations. At "detik.com" there are 66 news (10\%) in which there are scientific terms along with the explanation of the term. This, for example, was read on "detik.com" news entitled "England Reports Cases of Corona Virus Super-Spreaders, What It Means". In this news, "detik.com" journalists provide an explanation regarding the term called super-spreader. 


\section{Thematic Analysis}

The thematic analysis process wants to see the topic of conversation in a text. News texts speak "about what" or "about what". In thematic analysis, it is concluded that the theme of a text is read. Thematic analysis allows researchers to see the tendencies, attitudes and beliefs of a text. Researchers use reasoning in giving conclusions or topics from a text (Eriyanto, 2011). The thematic analysis in this study is divided into several parts, including health themes and news dimensions.

\section{Theme of Health}

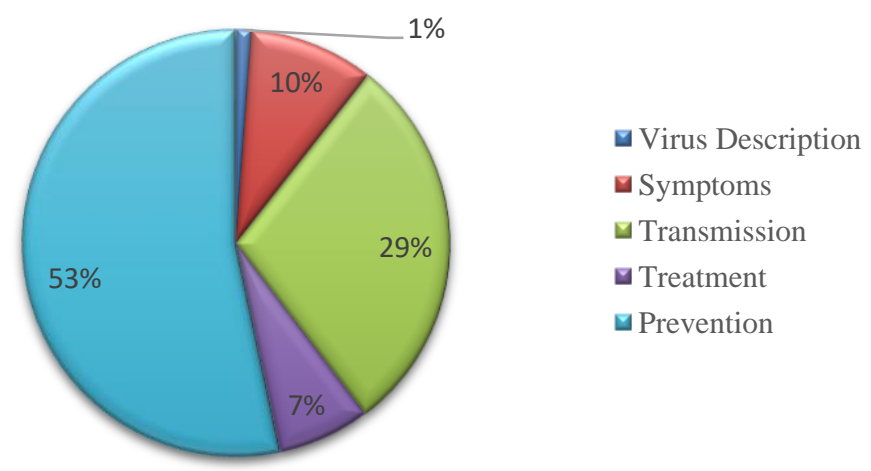

Figure 3. Health theme on detik.com

Explanations about health colored the news on the "detik.com" online media page. This health issue is related to the information submitted to deal with the spread of Covid-19. The Health theme in the news portal is divided into five parts: Prevention, spread, treatment, symptoms, and description of the virus. By observing the news in the online media, it is known that information about prevention dominates the news content. On the "detik.com" page, information about the prevention of Covid-19 is 367 news or (53\%). In the second rate, it shows 200 news items or (29\%).

In the third rate, "detik.com" discusses more the symptoms of Covid-19. A total of 65 news stories on "detik.com" (10\%) discussed the symptoms of Covid-19. On the other hand, discussions related to treatment on "detik.com" are only 48 news or (7\%), meaning that "detik.com" doesn't talk much about the description of Covid-19. The explanation regarding the description of the virus on the "detik.com" news page, it shows 8 of news or $(1 \%)$.

\section{News Dimension}

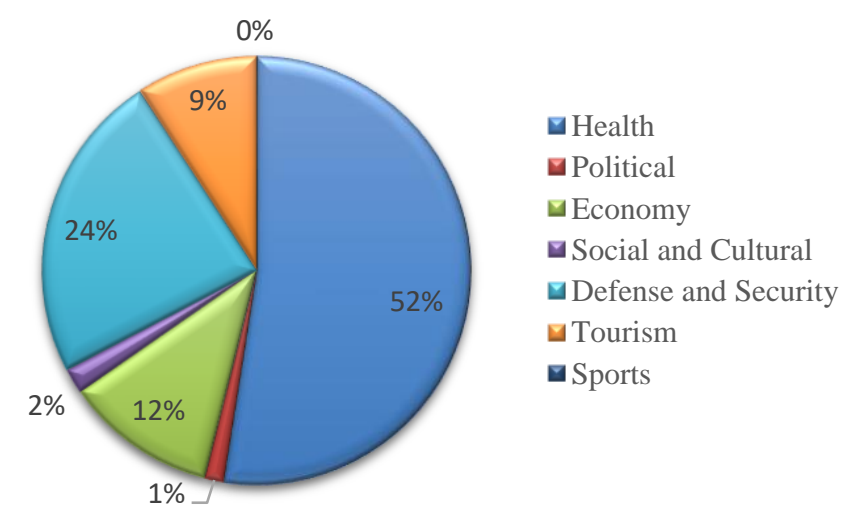

Figure 4. News Dimension of detik.com 
The news dimensions in "detik.com" are categorized into seven sections: health, defense and security, economy, tourism, politics, socio-culture, and sports. The researcher gave a code based on the dominant discussion topic. After conducting the quantification process, it was found that the most dominant discussion topic was the topic of health. The "detik.com" news page tends to talk about health. A total of 361 news $(52 \%)$ talk about health. This health topic relates to public health conditions, hospitals, and health access related to the spread of the coronavirus.

The discussion on the topic of defense and security is in the second rate. There are 162 news (24\%) on "detik.com". Information about the security anticipation at the airport is reported on this online media. The third order is the dominance of the topic of economic discussion. Narratives about economic conditions at both national and regional levels, changes in prices, and availability of food stocks are also discussed in this online media. There were 79 news stories (12\%) that discussed economic conditions. Then in the fourth rate, the discussion of tourism-related topics was 63 news $(9 \%)$.

In the fifth rate, topics about socio-culture were discussed, followed by political themes in the sixth rate. There are 13 of news (2\%) on detik.com that talks about sociocultural conditions. Then, news about politics appeared 10 of news (1\%). 688 news analyzed from "detik.com", there was no news that discussed the topic of sports, meaning that this media did not discuss the conditions experienced by athletes or athletes, including sportsmen's opinions regarding Covid-19.

In general, the news on "detik.com" focuses on the health theme. This is because the spread of Covid-19 is massive and is still relatively new. News about the spread of the Corona Virus is intensely discussed by this online media. The news is not only in Indonesia but also about the spread of the virus that has occurred in several countries. In addition, this online media also discusses the confirmation and increase of Covid-19 cases. However, in January "detik.com" tends to talk about pneumonia and a mysterious disease or new virus found in China. This can be seen in the news entitled "'Mysterious' Pneumonia Shocks China". Then, in February the news on "detik.com" tends to discuss the preparation, anticipation and handling of the virus in Indonesia. This can be seen in the news entitled "Ratas Degree on Corona Virus, Jokowi: Give Understanding so People Do not Panic". In March, news on "detik.com" tends to discuss patient management provision of personnel and medical equipment. For example, this can be seen in the news entitled " 2 Depok Residents Positive for Corona, West Java Health Office Deploys Team to Field.

\section{Empathy}

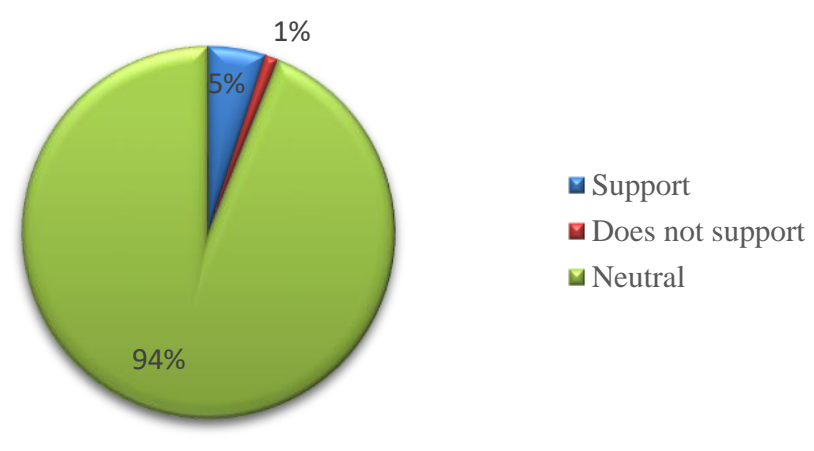

Figure 5. Emphaty on Detik.com 
News on "detik.com" tends to be neutral. This means that the packaged information does not favor one particular individual or group. The information presented is only a presentation of data and events. The data shows that there are 646 news $(94 \%)$ that are neutral. For example, this can be seen in the "detik.com" news entitled "The Death Toll Due to the Corona Virus in China Increases to 25 People". This news is a report from the Chinese authorities about the increase in victims in China and the spread of the coronavirus that has occurred in several countries outside China.

Seemingly, these online media news articles tend to be neutral. However, it is known that there are 34 articles (5\%) that are supportive of the sufferer or other related parties. This can be seen in the news entitled "This is How the Surabaya City Government Anticipates and Prevents the Coming of the Corona Virus". This news article describes a statement of support from the Surabaya Health Office by providing socialization to the public to prevent and be aware of the Corona Virus.

In addition, the articles in the handling of Covid-19, this news page also appears to display news that contains negative views that are negative towards sufferers or those who handle Covid-19. There are eight articles $(1 \%)$ of news that contain negative statements that do not support the handling of Covid-19. This can be read, for example, in a news article entitled "\#Tolaksementaraturischina Resounds. This is the Word of a Member of Commission I of the House". This news contains statements by Twitter users who reject the arrival of Chinese tourists. This rejection was also supported by members of Commission I of the House. This had caused a political commotion between Indonesia and China. This information will create chaos in the handling of Covid-19.

Detection of the Corona Virus began at the end of December 2019. On 31 December, the Chinese authorities reported finding a case of a viral infection that causes pneumonia at the Wuhan Sea-Food Market. This pneumonia case was confirmed on 3 January 2020, then WHO responded to this case on 10 January 2020. This disease is known to have spread outside China since 13 January 2020. News of "detik.com" is known as one of the first online media to provide information regarding the presence of pneumonia virus that causes pneumonia on 6 January 2020. The "detik.com" page contains news with the title "'Mysterious' Pneumonia Shocks China, Child in Singapore Was Isolated". This news was also followed by two other news hyperlinks updated on the same date with information about mysterious pneumonia. News of "detik.com" reports this disease as a mysterious pneumonia because there has been no response and examination from the WHO. The news was briefly presented, which reported about mysterious pneumonia. In addition, "detik.com" tends to provide information about cases of disease.

The online media "detik.com" focuses on providing information for the public during the Covid-19 pandemic. This media tends to display news in the form of direct news 651 of news $(95 \%)$, video news with 24 of news $(3 \%)$, and without news in the form of photos. Meanwhile, there were 361 news stories about Covid-19 (52\%), 367 news stories about prevention (53\%), treatment themes 48 news stories (7\%) and eight news descriptions about the virus (1\%). In the news during the pandemic, there are new scientific terms. It is known that there are 622 news articles $(90 \%)$ that use scientific terms without an explanation and 62 news articles (10\%) that include an explanation of scientific terms. The news displayed on the "detik.com" page is mostly neutral in tone. On "detik.com", 646 stories (94\%) were neutral in tone, $34(5 \%)$ were read as supporting or having empathy, and eight news articles that did not support or without 
empathy $(1 \%)$.

The events of the Covid-19 pandemic that have spread throughout the world have been widely reported by various mass media. The issue of the Corona Virus appeared on the main page of the media. Discussions and explanations about Covid-19 attracted the attention of citizens in various parts of the world, including Indonesia. The media covers the pandemic with diverse agendas and perspectives. Information about Covid19 and its consequences causes has become an attraction for media activists in presenting news. This is because people need comprehensive information to survive the pandemic. The public is educated by the media to survive during a pandemic. The media is a funnel of information from the government, health experts, and policymakers to the public regarding health management (Keshvari, Yamani, Adibi, \& Shahnazi, 2018). The media can educate the public to manage risk and encourage integrated and synergistic problem handling (Budi HH, 2012). The media is responsible for providing knowledge and understanding about health. Media information affects people's knowledge and trust. The knowledge that is integrated between traditional knowledge and the latest scientific findings will give birth to new knowledge that changes people's views, attitudes and behavior (Wardyaningrum, 2018). Thus, the media is responsible for providing information about disasters (pandemics) (Lestari \& Rinasti, 2020; Lestari, 2019).

Journalism is carried out by journalists to support the handling of the Covid-19 pandemic. In this case, journalists create content that promotes health. The content in the media can influence the decisions of doctors and policymakers in implementing health behavior (Arif, 2020; Yoedtadi, 2020). People's lifestyles are influenced by the information present in the media. Therefore, factual information appears to be accurate, complete, and reliable. Information can be provided directly based on a scientific approach that is suspected of being skeptical and independent (Kemenristek/BRIN, 2020). In this case, journalists need to build a balanced relationship with the government, health experts, researchers, and policymakers. Therefore, it takes the ability of journalists to manage information from reliable sources. Advances in information and communication technology allow the existence of varied information content. Verification from various sources needs to be done so that the information is valid and accurate. To support this, journalists can be sensitive and understand the map of the problems (Sukmono \& Junaedi, 2018). Furthermore, they avoid speculation and personal interpretation as much as possible in providing health information. Accurate and in-depth information is strength in health care (Keshvari et al., 2018). Although the speed of information is a mainstay for online media in sharing information, in the context of health, the completeness and accuracy of information accompanied by verification is strength in health journalism. as health information is related to human life (Arif, 2020; Parahita, 2020; Yoedtadi, 2020).

The pandemic causes a health crisis and creates false information related to the pandemic. It is called an infodemic. False statements and information, disinformation, hoaxes and racism are produced and spread in society. As of 5 May, 2020 there were 1,401 hoax and disinformation content circulating in the community through various platforms such as Facebook, Instagram, Youtube and Twitter (Yusuf, 2020). Excessive dramatization shown by the media to get clicks and views. The sensation and dramatization of news during a pandemic is a crisis for the world of journalism. Infodemic is a problem during the pandemic (Arif, 2020). UNESCO (United Nations Educational, Scientific and Cultural Organization) explained that the infodemic became 
the second outbreak after the corona virus due to the widespread spread of hoaxes and disinformation about the Corona Virus (UNESCO, 2020). It would be dangerous if the media quoted false statements that aroused the emotions of the readers. The instinct for economic and business gain can weaken the media to provide the public with the information they need. The media are partisan because they provide information to the public as well as package news that supports the sustainability of their media companies. Media speak with forked tongues in order to confuse the audience when they get information (Utomo, 2020). Therefore, it is important for the media turn out disasters into commodities (Budi HH, 2012).

The Covid-19 pandemic has affected journalistic work. According to AJI data, several journalists were reported to be infected with the virus (Madrim, 2020). Therefore, journalists are vulnerable to being infected with the virus. Chairman of the Alliance of Independent Journalists (AJI), Manan advised media companies to be careful in sending journalists to the field. If the risk is high, it is hoped that the coverage can be done online (Prodjo, 2020). To follow health procedures, media companies ask journalists to work from home by utilizing digital technology (Gandhawangi, 2020). It leads to maintaining the safety of journalists from exposure to the Covid-19 virus. Security and safety and journalists must pay attention to not becoming additional victims when covering news. In addition to reporting issues, reducing the workforce in the media, such as journalists, to the lack of media workers' income resulted in the weak quality of journalism being a problem during the pandemic (AJI, 2020).

The media can act as "watchdogs" to monitor of every narrative and government policy in handling the pandemic. For example, in the "detik.com" news article that appeared on 27 January 2020 with the title "Anticipation of the Corona Virus, Tightened Imports from China!" provides notes and encourages the government to be vigilant and anticipate the coronavirus. Criticism in a reasonable manner will help the government and society in dealing with the pandemic. As a "watchdog", the media encourages the government to make policies based on facts and field data and side with the public interest, especially vulnerable groups. About this, it appears in the news entitled "Menkes Prepares 100 Hospitals to Handle Corona Virus". This news provides an overview of the establishment of standard operating procedures by the government in hospitals. The media is a channel for the government to pass on information to the public. As a guard dog, the media monitors power so that the government is responsible for dealing with community problems (Putra, 2011). The government is an entity that is responsible for accommodating the public with adequate information. Hence, people can obey the rules (Susanto, 2011).

In delivering disaster news, the media frame thematic and sustainable information. Hence, the public understands and helps the public see the relationship between each event (Arif, 2011). News of "detik.com" is known to provide quite a lot of healthrelated information. There are 361 news articles (52\%) with a health dimension. Then, the theme of health about prevention is widely reported in this media. A total of 367 news articles $(53 \%)$ talk about preventing the coronavirus. In addition, information about cases updated is always reported by this media. During a pandemic, news can be displayed consistently, coordinated, timely and easily understood (compare Haddow, 2014; Paton \& Irons, 2016), but "detik.com" tends not to provide information. Explanation of the scientific terms used. A total of 622 news articles (90\%) included scientific terms without being accompanied by explanations. The accuracy of using and explaining data and terms is important for journalists to avoid other disasters (Sukmono 
\& Junaedi, 2018). Public literacy and education about health are carried out by the media to support efforts in managing health. Therefore, the media presents relevant topics rather than implicate events that create noise and fear in the community (Parahita, 2020).

Pandemic journalism creates public awareness and provides solutions to every problem during a pandemic. This can be seen in the news on 5 March 2020 entitled "DKI Provincial Government: Today 30 people are being monitored regarding Corona, 145 people are monitored". This information can raise public awareness to be aware of the dangers of the spread of the Corona Virus. Coverage during the pandemic pays attention to the economically weak, neglected people, and people with disabilities. It is because they are a vulnerable group of people due to the pandemic. News is presented with information that builds optimism (Asteria, 2016; Junaedi, 2011; Junaedi \& Sukmono, 2018), increases a sense of solidarity, and embraces collaboration to survive (Arif, 2020). In addition, pandemic journalism also supports medical needs, encourages government openness and reduces stigmatization of survivors. The media takes a role in reminding and increasing public awareness about the risks of a pandemic in reducing panic that occurs in society (Arif, 2020; Parahita, 2020; Utomo, 2020; Yoedtadi, 2020).

\section{Conclusion}

News about Covid-19 has been widely discussed in international and local media. The public needs information, and the media educates the public in dealing with the pandemic. The study showed that "detik.com" is an online media that provides information in the form of direct news with a neutral tone. News that has health and economic dimensions is known to be lacking. Information about the description of the virus and matters relating to prevention and treatment procedures need attention from this news portal. News about these things is important because it can add insight to knowledge and raise public awareness about the Covid-19 pandemic.

The "detik.com" news portal can provide focus and attention on health issues regarding the Covid-19 pandemic. The handling and empowerment efforts are informed to the public with a comprehensive approach accompanied by scientific knowledge and prioritizing empathy. Therefore, the depth and scientific information from scientists and health experts with in-depth explanations need to get more portions. So, people can implement daily life in accordance with health rules.

\section{Acknowledgements}

This research is supported by Atma Jaya University Yogyakarta.

\section{References}

Achmad, G. (2020, March). Jokowi Lamban Tangani Corona. GATRA, 8-13.

AJI. (2020, August). Menakar Jurnalisme pandemi di Media Kita.

Alexa. (2020). Top Sites in Indonesia.

Anggoro, S. (2012). Detikcom, Legenda Media Online. Yogyakarta: Mocomedia.

Arif, A. (2010). Jurnalisme Bencana, Bencana Jurnalisme. Jakarta: KPG.

Arif, A. (2011). Jurnalisme Bencana: Tugas Suci Praktik Cemar. In dkk Aswad Ishak (Ed.), Komunikasi Bencana (pp. 141-153). Yogyakarta: ASPIKOM.

Arif, Ahmad. (2020). Melawan Pandemi dengan Data dan Jurnalisme. In Webinar Bagaimana Meliput dan Menulis Pandemi COVID-19.

Asteria, D. (2016). Optimalisasi Komunikasi Bencana Di Media Massa Sebagai 
Pendukung Manajemen Bencana. Jurnal Komunikasi Ikatan Sarjana Komunikasi Indonesia, 01, 1-11.

BNPB. (2020). Virus Corona COVID-19 Lindungi Diri Lindungi Sesama.

Budi HH, S. (2012). Komunikasi Bencana: Aspek Sistem (Koordinasi, Informasi dan Kerjasama). Jurnal Komunikasi, 1(4), 363-372.

CDC. (2020). Coronavirus Disease 2019 (COVID-19).

Cecilia, S., Boer, R. F., \& Catherina, C. (2020). Citra Pemerintah Indonesia Di Acara Pembukaan Asian Games 2018: Analisis Isi Kuantitatif Pada Situs Berita Online Tribunnews.Com, Detik.Com \&amp; Liputan6.Com. Journal Komunikasi, 11(1). https://doi.org/10.31294/jkom

Detik.com. (2020). Inside Detik.com Redaksi.

Eriyanto. (2011). Analisis Isi Pengantar Metodologi untuk Penelitian Ilmu Komunikasi dan Ilmu-Ilmu Sosial Lainnya. Jakarta: Prenada Media Group.

Fauzan A H. (2020, March). Salah Kaprah Pemerintah Berujung Kepanikan Massal Terhadap Covid-19. Tirto.Id.

Febrina. (2020). Siaran Pers AJI yogyakarta: Jurnalis Perhatikan Keselamatan Meliput Pandemi COVID-19.

Foust J. C. (2017). Online Journalism: Principles and Pratices of News for The Web (Third). Taylor \& Francis.

Gandhawangi, S. (2020, April 3). Media di Tengah Pandemi Covid-19, Keselamatan Jurnalis Tetap yang Utama. Kompas.Id. Retrieved from https://www.kompas.id/baca/bebas-akses/2020/04/03/keselamatan-jurnalis-jadiprioritas/

Haddow, G. D. dan H. K. S. (2014). Disaster Communication In A Changing Media World (Second). Amsterdam: Elsevier.

Hadi, M. S., Argawa, M., Alfiyah, N., \& Hasyim, I. (2020, March). Siasat Bertahan dari Wabah. Majalah.Tempo.Co.

Hidayat, R. (2020, March). Teledor Penanganan Wabah Covid-19 di Indonesia. Tirto.Id. Junaedi, F. (2011). Manajemen Penyiaran Berita Bencana. In A. Ishak, S. Budi HH, F. Junaedi, \& A. Prabowo (Eds.), Komunikasi Bencana (pp. 207-223). ASPIKOM.

Junaedi, Fajar, \& Sukmono, F. G. (2018). Menggagas Jurnalisme Optimis dalam Pemberitaan Tentang Bencana. Jurnal Ilmu Komunikasi FISIP UAJY, 15 Nomor $1,107-120$.

Kemenkes. (2021, January). Situasi COVID-19.

Kemenristek/BRIN. (2020, February). Menyikapi Virus Corona 2019 n-CoV: Lembaga Eijkman untuk Indonesia. Indonesia: Youtube.

KEMKES RI. (2020). Kesiapsiagaan Menghadapi Infeksi COVID-19.

Keshvari, M., Yamani, N., Adibi, P., \& Shahnazi, H. (2018). Health Journalism: Health Reporting Status and Challenges. Iranian Journal of Nursing and Midwifery Research, 23 No.1, 14-17. https://doi.org/10.4103/ijnmr.IJNMR_158_16

Kompas. (2020, March). Indonesia Memasuki Fase Kritis Pandemi Covid-19. KOMPAS, p. 1,11 .

KSP. (2020). Penanganan Covid-19 Protokol Kesehatan. Jakarta.

Lee, M. (2008). Media Relations and External Communications during a Disaster. In J. Pinkowski (Ed.), Disaster Management Handbook (pp. 387-399). Boca Raton, London, New York: CRC Press Taylor and Francis Group.

Lestari, P. (2019). Manajemen Komunikasi Bencana Melalui Komunikasi Massa. In Perspektif Komunikasi Bencana (pp. 121-188). Yogyakarta: PT. Kanisius. 
Lestari, P., \& Rinasti, H. A. (2020). Menyingkap Perspektif Tunggal Dalam Komunikasi Bencana Erupsi Gunung Sinabung Melalui Detik.com. Bricolage: Jurnal Magister Ilmu Komunikasi, 6(01). https://doi.org/10.30813/bricolage.v6i01.2071

Luqman, H. M. (2017). Kecenderungan Pemberitaan Meikarta dalam Portal Berita Online: Analisis isi Kuantitatif pada Laman Detik.com, Liputan6.com, Kompas.com periode 1 Agustus-30 September 2017. UIN Sunan Ampel Surabaya.

Madrim, S. (2020). 242 Jurnalis dan Pekerja Media Positif Virus Corona. Retrieved December 12, 2020, from VOA website: https://www.voaindonesia.com/a/jurnalis-dan-pekerja-media-positifcorona/5599430.html

Parahita, G. D. (2020). Lima Dimensi Jurnalisme Krisis COVID-19. In Wawan Mas'udi \& Poppy S. Winanti (Eds.), Tata Kelola Penanganan COVID-19 di Indonesia: Kajian Awal (pp. 321-341). Yogyakarta: Gadjah Mada University Press.

Paton, D., \& Irons, M. (2016). Communication, Sense of Community, and Disaster Recovery: A Facebook Case Study. Frontiers in Communication, 1. https://doi.org/10.3389/fcomm.2016.00004

Pemerintah Daerah DIY. (2020). Yogyakarta Tanggap COVID-19.

Prajarto, N. (2008). Bencana, Informasi dan Keterlibatan Media. Jurnal Ilmu Sosial Dan Ilmu Politik, 11(3), 287-306. https://doi.org/10.22146/JSP.10989

Prodjo, W. A. (2020, August 5). Sejumlah Wartawan Positif Covid-19, Ini Imbauan AJI. Kompas.Com. Retrieved from https://megapolitan.kompas.com/read/2020/08/05/09335481/sejumlah-wartawanpositif-covid-19-ini-imbauan-aji?page=all

Purnomo, I. W. (2020, March). Menyangkal Krisis Menuai Bencana. Tempo.Co.

Putra, I. G. N. (2011). Demokrasi dan Kinerja Pers Indonesia. In S. Budi (Ed.), Media dan Demokrasi. Yogyakarta: ASPIKOM dan Buku Litera.

Rahmayanti, R. (2017). Objektivitas Pemberitaan Kasus Korupsi E-KTP pada Detik.com dan Liputan6.com: Analisis Isi Kuantitatif. Universitas Multimedia Nusantara.

Romli, A. S. (2012). Jurnalistik Online: Panduan Mengelola Media Online. Bandung: Nuansa Cendikia.

Sanusi, H. (2018). Jurnalisme dan Bencana (Refleksi Peran Jurnalis dalam Liputan Bencana Gempa, Tsunami dan Likuifaksi Palu-Donggala). Jurnal Jurnalisa. https://doi.org/10.24252/jurnalisa.v4i2.6895

Sinambela, D. B. (2020). Pertaruhan Jurnalis di Tengah Pandemi.

Sugiyono. (2015). Metode Penelitian Kuantitatif Kualitatif dan R\&D. Bandung: Alfabeta.

Sukmono, F. G., \& Junaedi, F. (2018). Jurnalisme Sensitif Bencana dalam Manajemen Pencarian, Pengelolaan, Informasi dan Pemberitahuan Bencana di Ruang Redaksi. Jurnal Aspikom, 3(4), 712-721.

Susanto, E. H. (2011). Eksistensi Komunikasi dalam Menghadapi Bencana. In A. Ishak, F. Junaedi, S. Budi HH, \& A. Prabowo (Eds.), Komunikasi Bencana (pp. 3-20). ASPIKOM.

Taher, A. P., \& Abdi, A. P. (2020). Jurnalis Selama Corona: Upah Telat, Meninggal Tanpa Perlindungan.

Thaniago, R. (2020). Indeks Media Inklusif 2020, Rapor Jurnalisme Daring Dalam Pemberitaan Kelompok Marginal di Indonesia. 
UNESCO. (2020). Combating the Disinfodemic: Working for Truth in the Time of COVID-19.

Utomo, W. P. (2020). Jurnalisme Krisis dan Krisis Jurnalisme di Era COVID-19. In Wawan Mas'udi \& Poppy S. Winanti (Eds.), Tata Kelola Penanganan COVID-19 di Indonesia: Kajian Awal (pp. 300-320). Yogyakarta: Gadjah Mada University Press.

Wahl-Jorgensen, K., \& Hanitzsch, T. (2019). Journalism Studies: Developments, Challenges and Future Directions. in The Handbook of Jounalism Studies (Second, pp. 3-20). New York: Routledge.

Waldometer. (2021, January). COVID-19 Coronavirus Pandemic.

Wardyaningrum, D. (2018). Kepercayaan Masyarakat Terhadap Informasi Tradisional dan Modern pada Peristiwa Bencana Alam. Jurnal Aspikom, 3(4), 609-622.

WHO. (2020). Corona Virus Disease (COVID-19) News.

WHO. (2020). Coronavirus Disease (COVID-19) Situation Reports.

Wisanggeni, S. P. (2020, March). Indonesia Butuh Riwayat Pelacakan Kontak Pasien Covid-19 yang Komprehensif dan Terbuka. Kompas.Id.

Yoedtadi, M. G. (2020). Jurnalisme Kesehatan di Tengah Pandemi COVID-19.

Yusuf. (2020). Kominfo Temuka 1.401 Sebaran Isu Hoaks Terkait COVID-19. 